\title{
Complete genome sequence and genomic characterization of Microcystis panniformis FACHB 1757 by third-generation sequencing
}

\author{
Jun-Yi Zhang ${ }^{1,2 \dagger}$, Rui Guan ${ }^{1 \dagger}$, Hu-Jun Zhang ${ }^{2}$, Hua Li ${ }^{3}$, Peng Xiao ${ }^{4}$, Gong-Liang Yu ${ }^{3}$, Lei Du ${ }^{5}$, De-Min Cao ${ }^{5}$, \\ Bing-Chuan Zhu' ${ }^{2}$ Ren-Hui Li ${ }^{3}$ and Zu-Hong Lü ${ }^{1,6^{*}}$
}

\begin{abstract}
The cyanobacterial genus Microcystis is well known as the main group that forms harmful blooms in water. A strain of Microcystis, M. panniformis FACHB1757, was isolated from Meiliang Bay of Lake Taihu in August 2011. The whole genome was sequenced using PacBio RS II sequencer with 48-fold coverage. The complete genome sequence with no gaps contained a 5,686,839 bp chromosome and a 38,683 bp plasmid, which coded for 6,519 and 49 proteins, respectively. Comparison with strains of $M$. aeruginosa and some other water bloom-forming cyanobacterial species revealed large-scale structure rearrangement and length variation at the genome level along with 36 genomic islands annotated genome-wide, which demonstrates high plasticity of the M. panniformis FACHB1757 genome and reveals that Microcystis has a flexible genome evolution.
\end{abstract}

Keywords: Microcystis panniformis FACHB1757, Microcystis, Lake Taihu, Water bloom, Third-generation sequencing, Comparative genomics

\section{Introduction}

The massive development of bloom-forming cyanobacteria is causing problems in eutrophic water bodies worldwide. Among the cyanobacteria, Microcystis is perhaps the most notorious. Many Microcystis species have been reported to be able to produce microcystins [1-4], which threaten many aquatic ecosystems and cause serious and occasionally fatal human liver, digestive, neurological, and skin diseases [5-7].

Microcystis is a genus of unicellular colony-forming cyanobacteria whose taxonomy is still unclear [8]. Although morphological criteria have been proposed to distinguish Microcystis species from field samples, such criteria have long been questioned for use in species identification within the genus [9]. Several studies

\footnotetext{
* Correspondence: zhlu@seu.edu.cn

${ }^{\dagger}$ Equal contributors

${ }^{1}$ State Key Laboratory of Bioelectronics, School of Biological Sciences and

Medical Engineering, Southeast University, Nanjing 210096, China

${ }^{6}$ Department of Biomedical Engineering, College of Engineering, Peking

University, Beijing 100871, China

Full list of author information is available at the end of the article
}

attempted to reconcile molecular and morphological taxonomy in Microcystis [9-14], and a morphologybased taxonomic system has been dominantly used. Microcystis panniformis was first reported in 2002 and was morphologically described as having flattened, irregular, monolayer colonies with small holes inside and later disintegrated into small pieces [15]. Since the $M$. panniformis strain SPC 702 was successfully isolated from Lago das Garças, São Paulo in 1999, studies addressing different aspects of this species have been performed [16-25]. In China, M. panniformis was reported as a newly recorded species in 2012 [26], and one strain (FACHB1757) was isolated from Lake Taihu. Microcystis panniformis was originally thought to only be distributed in tropical regions, but we showed that this species has invaded the subtropical regions with a monsoon climate [26]. Global expansion of harmful cyanobacteria has been thought to be linked to climate changes, particularly increasing amounts of atmospheric $\mathrm{CO}_{2}$ and surface temperature, which may promote Microcystis growth and enhance the potential for bloom 
occurrence [27-29]. Therefore, a deeper understanding of the ecology and physiology of $M$. panniformis FACHB1757 by obtaining a robust genome reference may provide insight into the expansion and invasion mechanisms of Microcystis.

\section{Organism information}

\section{Classification and features}

A water bloom sample was collected directly from the water surface using a plastic bucket in Meiliang Bay of Lake Taihu in August 2011 (Fig. 1a). Lake Taihu (E 30 $\left.56-31^{\circ} 33, \mathrm{~N} 119^{\circ} 54-120^{\circ} 36\right)$, the third largest freshwater lake in China, is located in the south of the Yangtze River Delta. The total area of the lake is $2338 \mathrm{~km}^{2}$, with an average depth of $2 \mathrm{~m}$ and total capacity of $47.6 \times 10^{8} \mathrm{~m}^{3}$. Lake Taihu is situated in the subtropical zone with a humid and semi-humid monsoon climate, and has suffered from severe eutrophication over the past three decades. Meiliang Bay is located in the northern part of Lake Taihu (Fig. 1a), which has a surface area of $100 \mathrm{~km}^{2}$, depth of $1.8-2.3 \mathrm{~m}$, and is currently hypereutrophic [30].

Some Microcystis colonies in the sample disintegrated during the sample collection process; thus, only those macroscopic colonies with significant monolayer were collected with 3 -ml pipets (BD Falcon, USA), and transferred into 50-ml centrifuge tubes (Corning, USA), and immediately shipped to the laboratory. Finally, macroscopic colonies that had flattened irregular up to monolayers with small holes (in old colonies) were identified as M. panniformis by examination under an optical microscope. Microcystis panniformis FACHB1757 was obtained, and this strain was then stored at the Freshwater Algae Culture Collection at the Institute of Hydrobiology, Chinese Academy of Sciences.

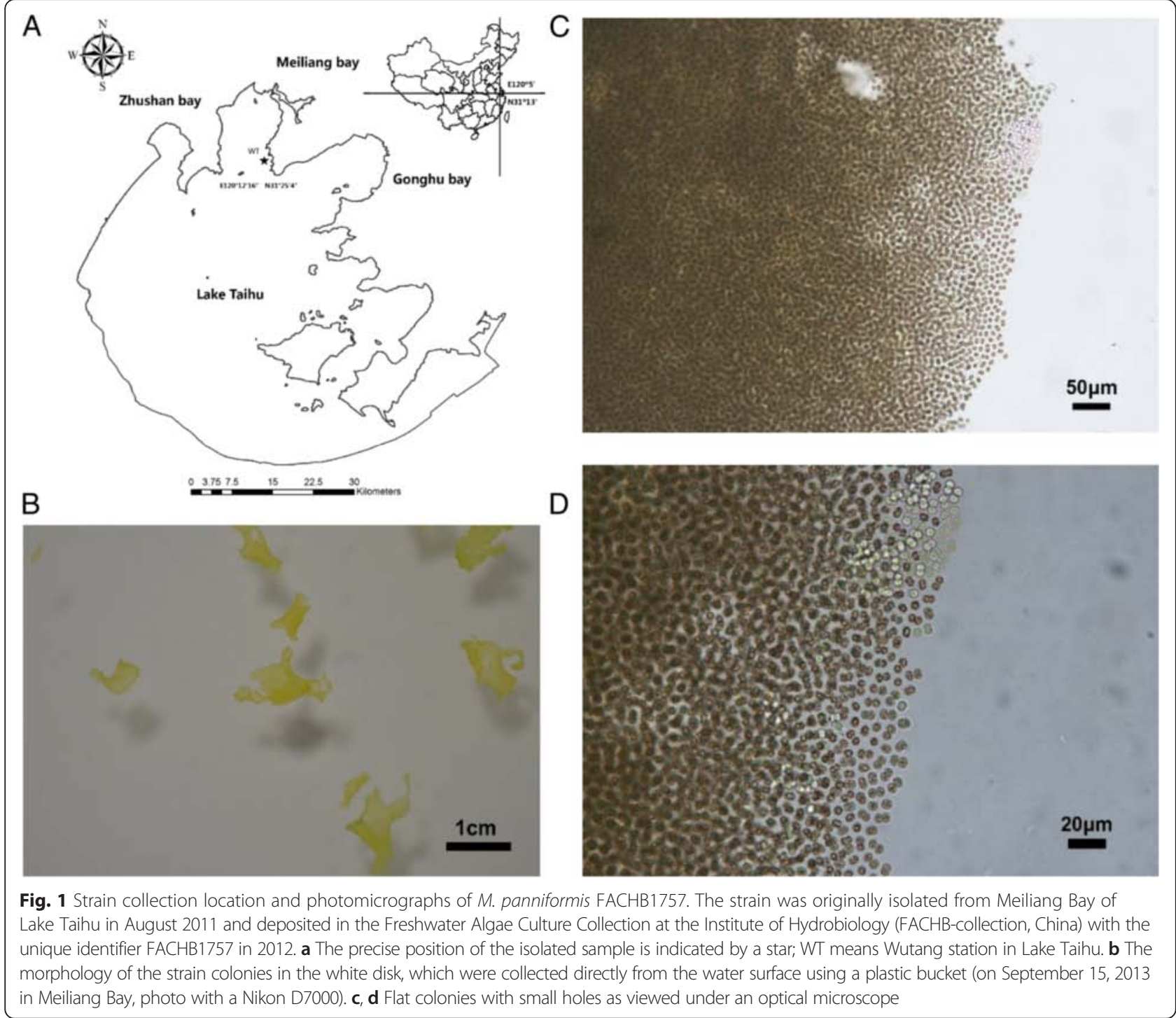


The general characteristics of $M$. panniformis FAC HB1757 are summarized in Table 1, and a phylogenetic tree based on 16S rRNA sequences is shown in Fig. 2. The spherical cells are estimated with a diameter of 2.6 to $6.8 \mu \mathrm{m}$ (mean $4.7 \mu \mathrm{m}$ ), be densely agglomerated, and form irregular colonies with small holes. The young stages formed small clusters of cells, which were flat or circular in outline, sometimes spheroidal, and with or

Table 1 Classification and general features of M. panniformis FACHB1757 according to the MIGS recommendations [69]

\begin{tabular}{|c|c|c|c|}
\hline MIGS ID & Property & Term & Evidence code $^{a}$ \\
\hline & Classification & Domain Bacteria & TAS [70] \\
\hline & & Phylum Cyanobacteria & TAS $[71,72]$ \\
\hline & & $\begin{array}{l}\text { Class } \\
\text { Oscillatoriophycideae }\end{array}$ & TAS [73] \\
\hline & & Order Chroococcales & TAS $[73,74]$ \\
\hline & & Family Microcystaceae & TAS [74] \\
\hline & & Genus Microcystis & TAS $[71,75]$ \\
\hline & & Species M. panniformis & $\operatorname{TAS}[15,31]$ \\
\hline & & $\begin{array}{l}\text { Strain: M. panniformis } \\
\text { FACHB1757 }\end{array}$ & TAS [26] \\
\hline & Gram stain & Gram-negative & TAS [76] \\
\hline & Cell shape & Spherical cells & TAS [15] \\
\hline & Motility & Non-motile & NAS \\
\hline & Sporulation & None & TAS [76] \\
\hline & $\begin{array}{l}\text { Temperature } \\
\text { range }\end{array}$ & Mesophile & NAS \\
\hline & $\begin{array}{l}\text { Optimum } \\
\text { temperature }\end{array}$ & $29.5^{\circ} \mathrm{C}$ & IDA \\
\hline & $\begin{array}{l}\text { pH range; } \\
\text { Optimum }\end{array}$ & $\mathrm{pH} 7.50-9.21 ; \mathrm{pH} 8.33$ & IDA \\
\hline & Carbon source & Autotroph, heterotroph & NAS \\
\hline MIGS-6 & Habitat & Fresh water & NAS \\
\hline MIGS-6.3 & Salinity & $1.0 \%$ (maximum) & IDA \\
\hline MIGS-22 & $\begin{array}{l}\text { Oxygen } \\
\text { requirement }\end{array}$ & Aerobic & NAS \\
\hline MIGS-15 & $\begin{array}{l}\text { Biotic } \\
\text { relationship }\end{array}$ & Free-living & NAS \\
\hline MIGS-14 & Pathogenicity & Microcystins (MCY) & $\operatorname{TAS}[25,77]$ \\
\hline MIGS-4 & $\begin{array}{l}\text { Geographic } \\
\text { location }\end{array}$ & $\begin{array}{l}\text { Isolated Lake Taihu, } \\
\text { China }\end{array}$ & IDA \\
\hline MIGS-5 & $\begin{array}{l}\text { Sample } \\
\text { collection }\end{array}$ & August, 2015 & IDA \\
\hline MIGS-4.1 & Latitude & $31.421 \mathrm{~N}$ & IDA \\
\hline MIGS-4.2 & Longitude & $120.201 E$ & IDA \\
\hline MIGS-4.3 & Depth & Surface $0.5 \mathrm{~m}$ & IDA \\
\hline MIGS-4.3 & Altitude & $11 \mathrm{~m}$ & IDA \\
\hline
\end{tabular}

${ }^{a}$ Evidence codes - IDA Inferred from Direct Assay, TAS Traceable Author Statement (i.e., a direct report exists in the literature), NAS Non-traceable Author Statement (i.e., not directly observed for the living, isolated sample, but based on a generally accepted property for the species, or anecdotal evidence). These evidence codes are from the Gene Ontology project [78] without an internal hollow. The old stages formed colonies with small holes, which later disintegrated into small groups. The mucilage (margin of colonies) was diffuse, and cells did not overlap. The margin of the colonies was smooth or (in old colonies) irregular. Cell density was regular and evenly agglomerated, sometimes in indistinct rows. Diagnostic characteristics included flat colonies with small holes, toxicity, homogeneously arranged cells, and life cycle was characterized by distinct benthic and planktonic phases $[15,31]$. The distribution was tropical, and this is likely a pantropical species (e.g., S. Africa, N. Australia, S. America, Africa, China, Vietnam and New Zealand) [13, 15, 16, 26, 31, 32].

\section{Phylogenetic analysis}

Whole genome comparative analysis between $M$. panniformis FACHB1757 and 13 other cyanobacterial species was performed. General information of related genome data is shown in Table S1 (Additional file 1), and all data sets were downloaded from NCBI. The main water bloom-forming cyanobacterial species in freshwater and brackish water worldwide, particularly those in the Lake Taihu region, were included. Unicellular colony-forming Microcystis and filamentous heterocystous Dolichospermum (formerly known as the planktonic Anabaena) were the main components of cyanobacterial blooms in Lake Taihu [33]. The Aphanizomenon, Pseudanabaena, Cylindrospermopsis, Raphidiopsis, Planktothrix, Synechocystis, and Synechococcus species occurred as dominant species or accompanying species in blooms of Lake Taihu (including Lake Wuli) across different seasons. Among the 14 genome sequences, 691 single-copy gene families were annotated by OrthoMCL (version 2.0.9) [34], and MEGA6 [35] was used to construct a phylogenetic tree based on these sequences (Fig. 3).

The phylogenetic tree shows that $M$. panniformis FACHB1757 and $M$. aeruginosa NIES843 shared a significantly high similarity, and there was no clear division between $M$. panniformis and $M$. aeruginosa strains in the phylogenetic tree. The Microcystis lineage is distinct from the lineage that contains the unicellular Synechocystis, Synechococcus, and other multicellular cyanobacteria. Furthermore, the Synechocystis sp. PCC 6803 genome is more closely related to Microcystis than other strains. This result is congruent with previously published results based on 16S rRNA sequences [36-39]. Topological relationships between species in the phylogenetic tree based on single-copy gene families were generally consistent with the phylogenetic tree based on 16S rRNA sequences (Fig. 2).

Although Microcystis can be identified based on $16 \mathrm{~S}$ rRNA and single-copy gene families sequences at the genus level, taxonomy of Microcystis at the species level was controversial in the past few decades, and 


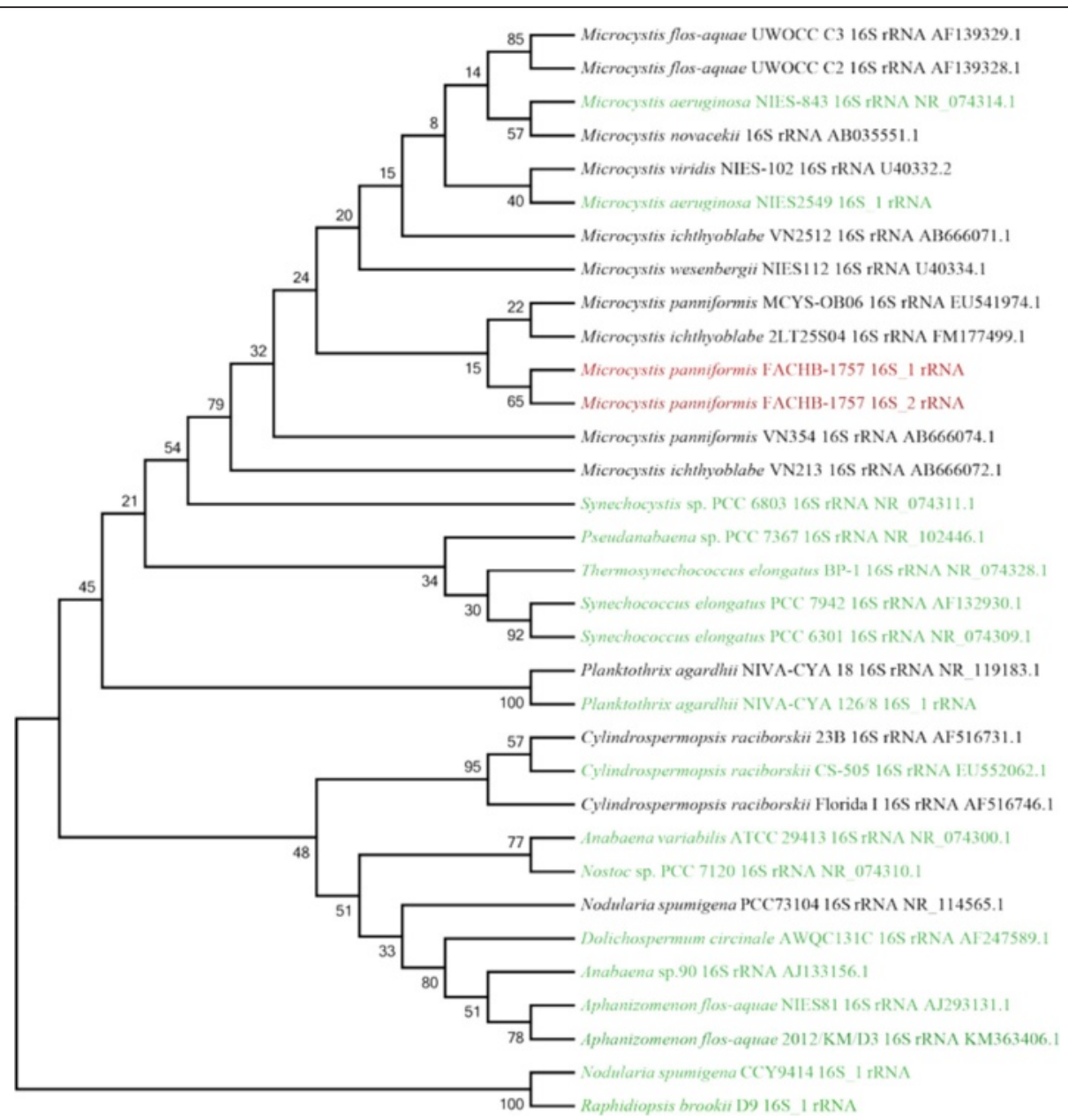

Fig. 2 Phylogenetic tree showing the position of M. panniformis FACHB1757. The dendrogram is based on the 165 ribosome RNA complete sequence of M. panniformis FACHB1757, M. aeruginosa NIES843, M. aeruginosa PCC7806, M. aeruginosa NIES 2549, and representatives of other cyanobacterial genera (Synechocystis, Pseudanabaena, Synechococcus, Thermosynechococcus, Planktothrix, Dolichospermum, Anabaena, Cylindrospermopsis, Nodularia, Nostoc, Aphanizomenon, Raphidiopsis) downloaded from NCBI (sequences without accession numbers were extracted from annotation files of the corresponding genomes) using the neighbor-joining algorithm with 100 bootstrap replications using MEGA6. A bootstrap consensus tree was constructed and is shown. The two copies of $16 \mathrm{~S}$ rRNA sequences of $M$. panniformis FACHB1757 are labeled in red. The relationship between M. panniformis FACHB1757 and other important algae species in Cyanophyceae are demonstrated. Species colored in green have whole genome data available in $\mathrm{NCBI}$

five species have even been unified into a single species [13]. 16S rRNA sequence estimation can be ambiguous when analyzing certain Microcystis species with distinct morphologies, as occurred when analyzing $M$. panniformis and M. ichthyobabe (Fig. 2). Therefore, the whole reference genome sequence data was expected to play a crucial role in species classification of Microcystis. However, the currently available cyanobacterial genome sequences are highly limited. Only three Microcystis strains with complete genomic sequences are available, including $M$. aeruginosa NIES843 and NIES2549, and M. panniformis FACHB1757 reported here. Furthermore, the further species concepts and more useful molecular approaches should be proposed to classify the species/strain divergences in Microcystis [40, 41].

\section{Genome sequencing information}

\section{Genome project history}

Microcystis panniformis FACHB1757 was selected for sequencing because of its obvious morphological characteristics; in particular, the macroscopic colonies with significant monolayer can even exceed $30 \mathrm{~mm}$ during the summer and early autumn in Lake Taihu. More importantly, until recently, only complete genomes of $M$. aeruginosa strains (including strains NIES843 and NIES2549) have been published. The complete genome sequence of $M$. panniformis FACHB1757 would only be the third for Microcystis. The sample information for $M$. panniformis FACHB1757 is available in NCBI under BioSample ID SAMN03392520. A DNA library with an insert size of $10 \mathrm{~Kb}$ was constructed, and the whole 


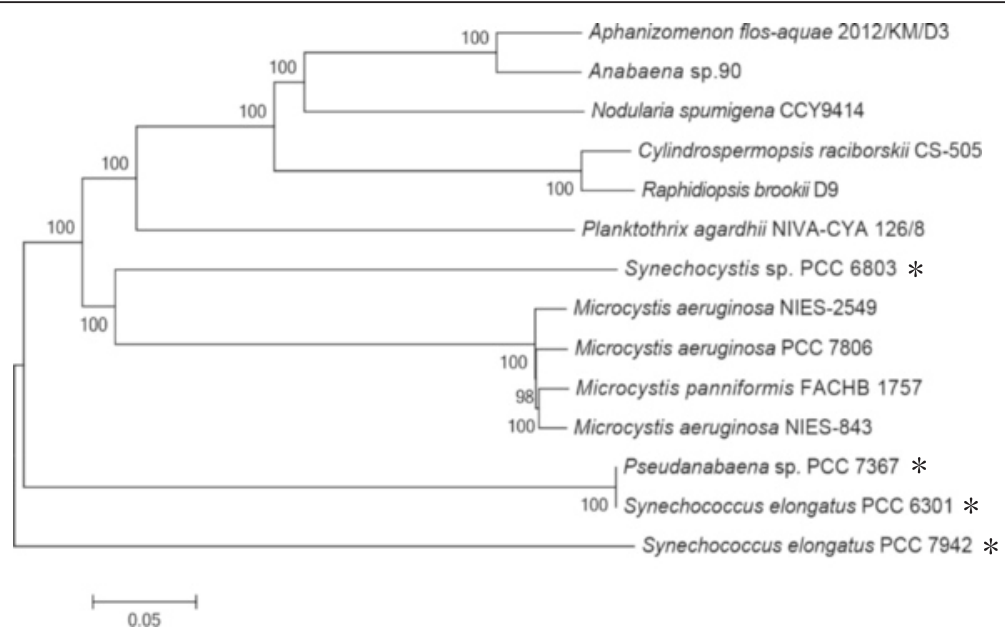

Fig. 3 Phylogenetic tree of water bloom-forming cyanobacterial species and representative cyanobacteria. The nucleotide divergence tree was constructed using the neighbor-joining algorithm based on 691 sequences of single-copy gene families annotated by OrthoMCL with 100 bootstrap replicates. The representative cyanobacteria that cannot form water blooms are indicated with an asterisk

genome was sequenced to 48 -fold coverage. The completed genome sequence was assembled and uploaded to GenBank under accession number. CP011339. Project details were deposited to NCBI BioProject PRJNA277430. A summary of the project information can be found in Table 2 .

\section{Growth conditions and genomic DNA preparation} Microcystis panniformis FACHB1757 colonies collected from the field were grown in MA medium [42] and incubated in 24-well culture plates for $4 \mathrm{wk}$. Then, floating colonies were transferred to the capped tubes that contained $5 \mathrm{ml}$ of MA culture medium to finally form a unialgal culture. All cultures were grown at $25 \pm 1{ }^{\circ} \mathrm{C}$ with a $12 \mathrm{~h}$ light/12 $\mathrm{h}$ dark cycle under a photon

Table 2 Project information

\begin{tabular}{lll}
\hline MIGS ID & Property & Term \\
\hline MIGS-31 & Finishing quality & Complete \\
MIGS-28 & Libraries used & 2 PacBio SMRT cells \\
MIGS-29 & Sequencing platforms & PacBio RSII \\
MIGS-31.2 & Fold coverage & 43.39 \\
MIGS-30 & Assemblers & HGAP 2.2.3 \\
MIGS-32 & Gene calling method & RAST \\
& Locus Tag & VL20 \\
& GenBank ID & CP011339 \\
& GenBank Date of Release & August 11, 2015 \\
& GOLD ID & Gp0111943 \\
& BIOPROJECT & PRJNA277430 \\
& Source Material Identifier & FACHB1757 \\
MIGS-13 & Project relevance & Environmental \\
\hline
\end{tabular}

irradiance of $25 \mu \mathrm{mol}$ photons $/\left(\mathrm{m}^{2} \cdot \mathrm{sec}\right)$ provided by daylight fluorescent lamps. Total genomic DNA of $M$. panniformis FACHB1757 was extracted using a commercial DNA isolation kit (DNeasy Plant Mini Kit, Qiagen, USA) following the manufacturer s instructions, and analyzed by micro-volume fluorescence detection (NanoDrop $^{\text {in }} 8000$ Spectrophotometer, Thermo Scientific, USA) and electrophoresis in $0.8 \%$ agarose gel stained with ethidium bromide. The isolated DNA was eluted with $50 \mu \mathrm{l}$ of the elution buffer from the commercial kit and then stored at $-20{ }^{\circ} \mathrm{C}$ until subsequent analyses.

\section{Genome sequencing and assembly}

First, the genome was surveyed using an Illumina Hiseq sequencer to detect the purity of the cultured unialgal strain. The insert size of the next generation pair-end library was $100 \mathrm{bp}$, and $1 \mathrm{Gbp}$ raw data was produced in total. All reads were mapped to the $M$. aeruginosa NIES843 reference complete genome, and more than $80 \%$ of reads matched well. Subsequently, the genome was sequenced using PacBio RS II. Genomic DNA was sheared by Covaris S220 g-TUBE. A $10 \mathrm{~Kb}$ library was constructed using a PacBio template prep kit and sequenced using the PacBio SMRT platform. In total, two SMRT cells were run, and 303 megabase pair raw data was obtained. After filtering, the mean read length was $7143 \mathrm{bp}$ with a quality of 0.84 , and the longest read was 31,225 bp. HGAP (version 2.2.3) was used for genome assembly. Long reads were chosen as seeds, and the other reads were mapped to the seeds using Blasr (version 1.3.1.132871) [43] for error correction. After alignment, the accuracy of seed sequences were optimized to $99 \%$ to meet the requirements of the Sanger assembly software. There was a total of 
$128 \mathrm{Mbp}$ of high quality long seed reads, which had an average length of $7898 \mathrm{bp}$. Celera Assembler (version 8.1) [44] was then used to assemble the seed reads into contigs and Quiver [45] was used for second error correction. Contigs were assembled into the final complete genome sequence using minimus2 in AMOS (version 3.1.0). The final genome consisted of a complete circular $5,686,839$ bp chromosome with a GC content of $42.35 \%$ and a 38,683 bp plasmid with a $43.97 \%$ GC content. Sequencing depths were 44.85 and 128.42 , respectively.

\section{Genome annotation}

TRs were predicted by Tandem Repeat Finder (version 4.07b) [46] and Microsatellite identification tool (version 1.0), which can both identify perfect and compound micro-satellites. Prediction and annotation of the genome were done using the RAST server (version 2.0) [47]. RAST integrated tRNAscan-SE, and the search_for_rnas tool was used to call RNA genes across the chromosome. For gene estimation, GLIMMER2 was used to represent putative genes. Subsequently, a similar search was performed against FIGfams to identify the determined genes and annotate their functions. Moreover, all putative protein-coding genes were assigned to a category using databases including Clusters of Orthologous Groups (COG), Gene Ontology (GO), Kyoto Encyclopedia of Genes and Genomes (KEGG), Swiss-Prot, and NonRedundant Protein Database.

\section{Genome properties}

The genome assembly contained a complete circular chromosome sequence $(5.69 \mathrm{M})$ and a plasmid (38.68 K). The schematic representation of the circular chromosome of M. panniformis FACHB1757 was showed in Fig. 4. Related genome assembly and annotation information can be found in Table 3. Nucleotide homology search of $M$. panniformis FACHB1757 and M. aeruginosa NIES843 genomes was conducted by BLAST, and similarity between the two species was $83.82 \%$ (Additional file 1: Figure S1). A total of 1944 TRs were found in the genome, including 27 microsatellites, 1742 mini-satellites, and 176 satellites. Genome statistics are shown in Table 4. In total, there were 6567 genes, which included 48 RNA genes and 6519 protein-coding genes. Among the 6519 proteins, most contained around 100 amino acids (Additional file 1: Figure S2), and by compared with function databases mentioned above, $60.15 \%$ of them were determined to have specific functions. There were 42 tRNA genes, and two copies of the rRNA gene cluster were found in the same direction. Function assignments of 6519 putative protein-coding genes were searched against several frequently used databases mentioned above; 3260 genes were assigned to COGs, of which 235 participated in signal transduction. Search of Pfam omains detected 3997 candidates. According to the subsystem classification results processed by RAST, $72 \%$ of determined genes belong to specific subsystems, and the distribution of each category is demonstrated in (Additional file 1: Figure S3). The result of COG function annotation is shown in Table 4, and details of each COG cluster can be found in Additional file 2 . The genes assigned to GO categories by InterProScane (version 5.4-47.0) [48] were classified into cellular components, molecular functions, and biological processes. Genes distributed in each category and their functions are shown in (Additional file 1: Figure S4). In the GO data, 309 signal function-related genes were found. KEGG matched 897 functional genes to related systems, as shown in (Additional file 1: Figure S5). Final gross function annotation outcomes are provided in (Additional file 1: Table S2).

\section{Insights from the genome sequence Comparative Microcystis species genomes Gene ortholog analysis}

Genes of four Microcystis species were compared (Fig. 5), and 2669 highly conserved orthologous genes were shared, which are representative of the core genome. Moreover, each genome had strain-specific genes, which varied from 296 to 1900 . The M. aeruginosa NIES2549 genome, which has 1388 unique genes, is $1.5 \mathrm{Mbp}$ smaller than that of M. aeruginosa NIES843, which only has 296 unique genes ( $M$. aeruginosa NIES843 has 1388). Microcystis panniformis FACHB1757 was shown to have 1900 specific genes, which was the greatest amount among the four strains, even though its genome was not the longest.

\section{Secondary metabolite gene clusters}

Microcystin was reported to enhance colony formation in Microcystis spp. and plays a key role in the persistence of their colonies and the dominance of Microcystis [49]. As in M. aeruginosa NIES843 and $M$. aeruginosa PCC7806 genomes, the microcystin synthetase gene cluster $(m c y A-J)$ was highly conserved in $M$. panniformis FACHB1757 from coordinates 3,496,704 to $3,541,027$. Additionally, the distinct thioesterase type II coding gene $m c y T$, which occurs in toxic strains, and 4PPT transferase (4-PPTase) were both located far from the $m c y$ gene cluster at coordinates 869,702 to 869,286 and 915,377 to 916,039 , respectively, which are similar to the distributions observed in $M$. aeruginosa NIES843. Notably, there was an absence of $m c n A$ and $m c n B$ in the $M$. panniformis FACHB1757 chromosome. $m c n A$ codes polyketide biosynthesis proteins, and $m c n B$ is the first open reading frame of mamestra configurata nucleopolyhedrovirus B. Together with $m c n C$ and $m c n E$, these four genes compose the cyanopeptolin 


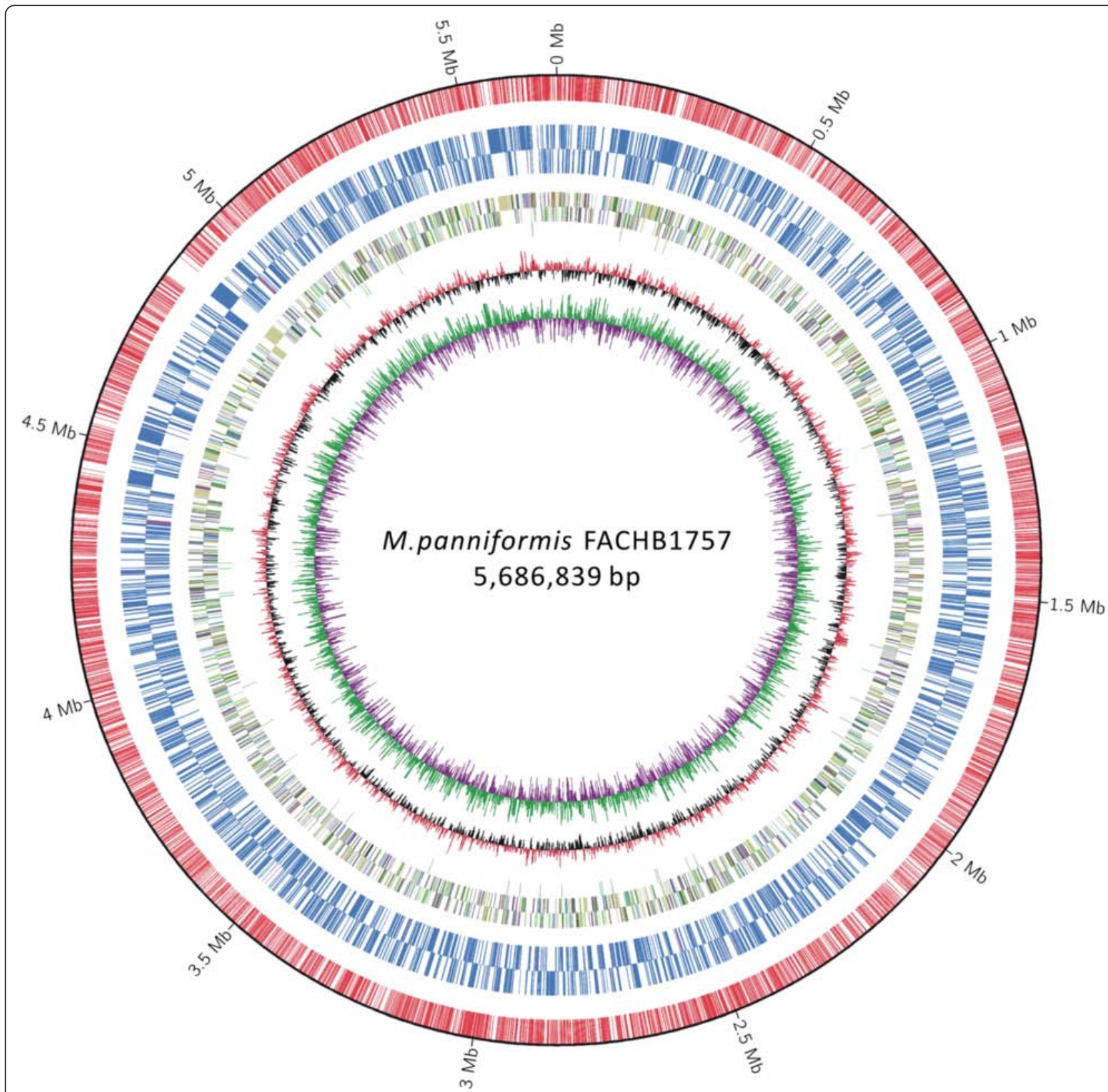

Fig. 4 Schematic representation of the circular chromosome of M. panniformis FACHB1757. The scales indicate location in Mbp, starting with the initial coding region. Using Circos integrated the gene prediction results of COG function annotation, methylated modification, and some other information. From inner to outer circles: the first circle shows the GC skew (in purple and green), and the value is plotted as the deviation from the average GC skew of the entire chromosome sequence. The bars in the second circle (in black and red) represent the GC content, which is plotted using a 10-Kb sliding window. Positions of tRNA and rRNA are marked by green bars in the third circle. Bars in the fourth and fifth circle are colored according to COG function categories of CDS; the fourth is a backward strand and fifth is a forward strand. The sixth and seventh circles indicate $\mathrm{m} 4 \mathrm{C}$ and $\mathrm{m6A}$ sites in CDS/rRNA/tRNA regions (in blue bars); the sixth circle is a backward strand and the seventh circle is a forward strand. In the eighth circle, red bars show the $\mathrm{m} 4 \mathrm{C}$ and $\mathrm{m} 6 \mathrm{~A}$ sites in intergenic regions

synthesis gene cluster. $m c n D$ was not found in the $M$. panniformis FACHB1757 genome; thus, the cyanopeptolin produced was non-halogenated and identical to that of $M$. aeruginosa NIES843 and PCC7806. Toxins may contribute to the adaptation of this strain to its specific ecological niche in eutrophic waters of tropical and subtropical zones. In addition, a putative polyketide synthase gene cluster, which may encode additional small polypeptides found in $M$. aeruginosa NIES843 (coordinates 2,508,556-2,513,289), was detected in $M$. panniformis FACHB1757 at coordinates $4,425,371$ to $4,430,104$. The change in location of the genes 
Table 3 Genome statistics

\begin{tabular}{lrr}
\hline Attribute & \multicolumn{1}{l}{ Value } & \% of Total \\
\hline Genome size (bp) & $5,686,839$ & 100.00 \\
DNA coding (bp) & $4,616,631$ & 81.18 \\
DNA G + C (bp) & $2,408,639$ & 42.35 \\
DNA scaffolds & 1 & 100.00 \\
Total genes & 6,567 & 100.00 \\
Protein coding genes & 6,519 & 99.27 \\
RNA genes & 48 & 0.73 \\
rRNA genes & 6 & 0.09 \\
tRNA genes & 42 & 0.64 \\
Pseudo genes & - & - \\
Genes in internal clusters & - & - \\
Genes with function prediction & 3,921 & 100.00 \\
Genes assigned to COGs & 3,373 & 86.02 \\
Genes with Pfam domains & 2,067 & 52.72 \\
Genes with signal peptides & 309 & 7.88 \\
CRISPR repeats & 3 & - \\
Genes with transmembrane helices & - & - \\
\hline
\end{tabular}

mentioned above reflected the extensive structural variation between $M$. panniformis FACHB1757 and M. aeruginosa NIES843.

\section{Conserved gene clusters}

Four functional clusters of conserved genes related to microcystin synthesis, colony formation, photoregulation, and nutrient assimilation were also compared among the four Microcystis strains. In the microcystin synthesis gene cluster, the mcy and $m c n$ gene clusters were not found in $M$. aeruginosa NIES2549. This is consistent with the results of a previous study, which showed that $M$. aeruginosa NIES2549 is a nontoxic strain [50]. With regard to colony formation, $M$. aeruginosa, $M$. wesenbergii, and $M$. panniformis all have typical macroscopic colony structure when observed by naked eye in Lake Taihu during summer and autumn water blooms. Microcystis panniformis seems to be the largest, and can even have more than $30 \mathrm{~mm}$ colonies. Polysaccharides and microcystin play important roles in the process of Microcystis colony formation. The maximum EPS content was found in $M$. wesenbergii and $M$. aeruginosa, which are not the largest and are only approximately $100 \mu \mathrm{m}$ [51], but positive correlations between EPS and Microcystis colony size in cultures were supported by previous studies [52-54]. $m r p C$ and epsL were absent from all four strains, and only $M$. aeruginosa NIES843 contained cpsF, although $\operatorname{tagH}, \operatorname{capD}, c s a B$, and $r f b B$ were conserved
Table 4 Number of genes associated with general COG functional categories

\begin{tabular}{|c|c|c|c|}
\hline Code & Value & $\%$ Age & Description \\
\hline J & 165 & 2.51 & $\begin{array}{l}\text { Translation, ribosomal structure } \\
\text { and biogenesis }\end{array}$ \\
\hline A & 0 & 0.00 & RNA processing and modification \\
\hline K & 131 & 1.99 & Transcription \\
\hline L & 620 & 9.44 & Replication, recombination and repair \\
\hline B & 1 & 0.02 & Chromatin structure and dynamics \\
\hline D & 47 & 0.72 & $\begin{array}{l}\text { Cell cycle control, Cell division, } \\
\text { chromosome partitioning }\end{array}$ \\
\hline V & 67 & 1.02 & Defense mechanisms \\
\hline $\mathrm{T}$ & 138 & 2.10 & Signal transduction mechanisms \\
\hline M & 203 & 3.09 & Cell wall/membrane biogenesis \\
\hline N & 30 & 0.46 & Cell motility \\
\hline U & 52 & 0.79 & Intracellular trafficking and secretion \\
\hline O & 152 & 2.31 & $\begin{array}{l}\text { Posttranslational modification, } \\
\text { protein turnover, chaperones }\end{array}$ \\
\hline C & 185 & 2.82 & Energy production and conversion \\
\hline G & 131 & 1.99 & Carbohydrate transport and metabolism \\
\hline E & 215 & 3.27 & Amino acid transport and metabolism \\
\hline $\mathrm{F}$ & 62 & 0.94 & Nucleotide transport and metabolism \\
\hline $\mathrm{H}$ & 146 & 2.22 & Coenzyme transport and metabolism \\
\hline । & 65 & 0.99 & Lipid transport and metabolism \\
\hline$P$ & 188 & 2.86 & Inorganic ion transport and metabolism \\
\hline Q & 126 & 1.92 & $\begin{array}{l}\text { Secondary metabolites biosynthesis, } \\
\text { transport and catabolism }\end{array}$ \\
\hline $\mathrm{R}$ & 535 & 8.14 & General function prediction only \\
\hline$S$ & 483 & 7.35 & Function unknown \\
\hline- & 2,826 & 43.02 & Not in COGs \\
\hline
\end{tabular}

The total is based on the total number of protein-coding genes in the genome

in all four strains. Furthermore, mvn codes for a lectin in $M$. panniformis FACHB1757 and $M$. aeruginosa PCC7806, which specifically binds to a sugar moiety present on the surface of Microcystis cells. Additionally, a binding partner of MVN was identified in the lipopolysaccharide fraction of $M$. aeruginosa PCC7806, which involved in the Microcystis colony formation [55]. Together, the toxin-, EPS-, and lectin-related genes may explain the reason why M. panniformis FACHB1757 usually aggregates and produces a larger colony in Lake Taihu during water blooms. In the photo-regulation cluster, $p s b$, $a p c$ and $g v p$ with the exception of $g v p C$ were all detected. It is interesting that $g \nu p C$ is absent from $M$. panniformis FACHB1757, because this gene encodes GvpC, which is a highly conserved expressed protein in some genera that is closely related to gas vesicles [56-58]. Genes related to nutrient assimilation include $n t c$, pst, and sph clusters. $n t c B$, pst $A$, pstB1, pstB2, and pstC were only absent from $M$. aeruginosa PCC7806 among the four strains, which 


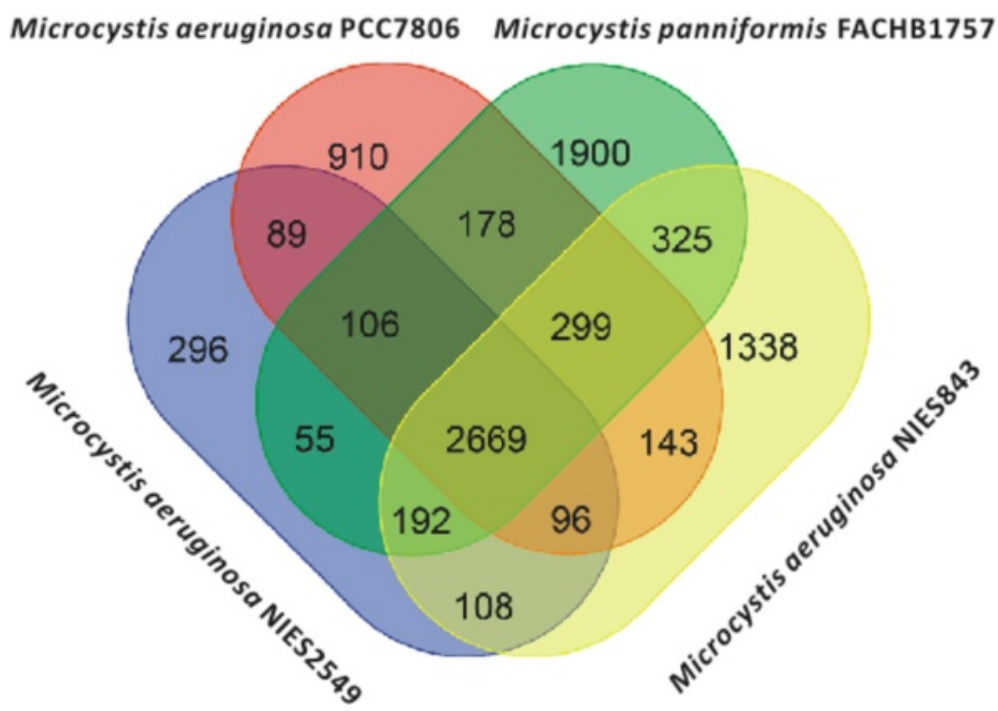

Fig. 5 Venn diagram of gene numbers of four Microcystis species. Less than half of all genes were found in all four species

may be accounted for by the incompleteness of the strain s genome. Detailed information about function and coordinates of each gene are shown in (Additional file 1: Table S3).

\section{Genome structure and constitution comparison}

The genomes of $M$. aeruginosa NIES843 and $M$. aeruginosa NIES2549 have no plasmids, whereas a $38 \mathrm{~Kb}$ plasmid with a $43.97 \%$ GC content was detected in $M$. panniformis FACHB1757 in this study. The stable presence of plasmids may play an important role in some Microcystis obtaining competitive advantages [59-61]. Microcystis aeruginosa NIES-843 is the first strain of the genus Microcystis to be sequenced for its complete genome with the ABI 3770xl sequencer. Since then, the second completed Microcystis genome (of M. aeruginosa NIES-2549) was released on the April 29, 2015. Thus, the whole genome at the nucleic acid level was compared between M. panniformis FACHB 1757 and $M$. aeruginosa NIES-843. Mauve, which was designed for identification and alignment of conserved genomic sequences with rearrangements and horizontal transfer, was used to conduct comparative genomic sequence analysis [62]. As shown in (Additional file 1: Figure S1), M. panniformis FACHB1757 underwent extensive chromosome structure rearrangement, which indicates that Microcystis genomes are highly plastic [36].

\section{Self-defense system}

\section{Restriction modification system}

Comparison with REBASE [63], a restriction enzyme database containing information about restriction enzymes, revealed that DNA methyltransferases and related proteins are involved in the biological process of $\mathrm{R}-\mathrm{M}$, and

Table 5 Sequence structure and general information of motifs in the whole genome

\begin{tabular}{|c|c|c|c|c|c|c|c|c|}
\hline Motif & $\begin{array}{l}\text { Modified } \\
\text { position }\end{array}$ & Type & $\begin{array}{l}\text { Motifs } \\
\text { detected }\end{array}$ & $\begin{array}{l}\text { \# of motifs } \\
\text { detected }\end{array}$ & $\begin{array}{l}\text { \# of motifs in } \\
\text { genome }\end{array}$ & $\begin{array}{l}\text { Mean } \\
\text { QV }\end{array}$ & $\begin{array}{l}\text { Mean motif } \\
\text { coverage }\end{array}$ & $\begin{array}{l}\text { Partner } \\
\text { motif }\end{array}$ \\
\hline GATC & 2 & $m 6 A$ & $78.55 \%$ & 37,874 & 48,218 & 45.44 & 22.91 & GATC \\
\hline GAATTC & 3 & $\mathrm{~m} 6 \mathrm{~A}$ & $74.54 \%$ & 1938 & 2,600 & 44.25 & 22.53 & GAATTC \\
\hline GCTGDAG & 6 & $m 6 A$ & $73.70 \%$ & 995 & 1,350 & 43.72 & 22.95 & - \\
\hline GGTGGA & 6 & $\mathrm{~m} 6 \mathrm{~A}$ & $70.96 \%$ & 1935 & 2,727 & 43.22 & 22.81 & - \\
\hline GACGNAC & 6 & $\mathrm{~m} 6 \mathrm{~A}$ & $70.26 \%$ & 723 & 1,029 & 42.58 & 23.11 & - \\
\hline ACCACC & 4 & $m 6 A$ & $69.67 \%$ & 2410 & 3,459 & 41.91 & 22.82 & - \\
\hline CAAGNNNNNNTTTC & 3 & $\mathrm{~m} 6 \mathrm{~A}$ & $69.02 \%$ & 176 & 255 & 41.45 & 21.48 & - \\
\hline GATATC & 2 & $\mathrm{~m} 6 \mathrm{~A}$ & $67.42 \%$ & 2055 & 3,048 & 42.29 & 23.09 & GATATC \\
\hline MCGRAG & 5 & $\mathrm{~m} 6 \mathrm{~A}$ & $52.23 \%$ & 3390 & 6,491 & 41.64 & 22.35 & - \\
\hline GCWGC & 2 & $\mathrm{~m} 4 \mathrm{C}$ & $24.17 \%$ & 3911 & 16,184 & 37.52 & 25.13 & GCWGC \\
\hline RGATCY & 5 & $\mathrm{~m} 4 \mathrm{C}$ & $19.09 \%$ & 808 & 4,232 & 36.99 & 25.80 & RGATCY \\
\hline GGCC & 3 & $\mathrm{~m} 4 \mathrm{C}$ & $18.02 \%$ & 3721 & 20,654 & 37.67 & 26.39 & GGCC \\
\hline
\end{tabular}






Fig. 6 GEls distribution in the chromosome of M. panniformis FACHB1757. From inside to outside, green bars illustrate IslandPick prediction, orange bars show the results annotated by SIGI-HMM, and blue bars are predicted by IslandPath-DIMOB. Red bars indicate integrated GEls candidate positions. Black line plot around the small circle reveal the GC content

277 restriction enzymes were found. Detailed classification revealed that 12 and 130 enzymes belonged to type I and type II systems, respectively, which together represented $46.93 \%$ of all enzymes, and are categories of rapidly evolving genes [64]. Sixty-three, 10, and 2 enzymes, respectively, belonged to type IIG, type III, and type IV systems, and one control protein restriction enzyme and 58 unknown enzymes were also found.

\section{Methylation modification analysis}

It is widely thought that methylation modification is associated with R-M systems and participates in self-defense against foreign genome invasion. Genome methylation modification and methyl-transferase recognition sequence motifs were analyzed using SMRT (version 2.3.0). In the chromosome, $3204 \mathrm{~m} 4 \mathrm{C}\left(\mathrm{N}^{4}\right.$-methylcytosine), 9,758 m6A ( $\mathrm{N}^{6}$-methyladenine), and 31,845 other

Table 6 Functions and types of all 36 GEls in chromosome

\begin{tabular}{|c|c|c|c|}
\hline Function & Advantage conferred & GEl type & Related GEls \\
\hline Alkaline phosphatase & Increased metabolic versatility & Metabolic & GEI2,GEI7,GEI10,GEI17,GEI19,GEI23,GEI26,GEI27, \\
\hline $\begin{array}{l}\text { Toxin/Antitoxin } \\
\text { protein }\end{array}$ & Competitiveness & $\begin{array}{l}\text { Pathogenicity, } \\
\text { resistance }\end{array}$ & GEl1,GEl6,GEl13,GEI31,GEI32,GEI33 \\
\hline Transferase & Increased metabolic versatility & Metabolic & GEI4,GEI9,GEI15,GEI21,GEI24,GEI25,GEI30,GEI36 \\
\hline Transposase & Increased metabolic versatility & Metabolic & $\begin{array}{l}\text { GEl1,GEl3,GEl4,GEl1 1,GEl12,GEl15,GEl16,GEl18, } \\
\text { GEl24,GEI29,GEI34 }\end{array}$ \\
\hline Hat/HatR & $\begin{array}{l}\text { Increased metabolic versatility, increased } \\
\text { adaptability }\end{array}$ & Fitness & GEI11,GEI28 \\
\hline Heat shock protein & $\begin{array}{l}\text { Increased metabolic versatility, increased } \\
\text { adaptability }\end{array}$ & Synthesis, fitness & GEI31 \\
\hline PsaE & Increased metabolic versatility & Metabolic, fitness & GEI9 \\
\hline
\end{tabular}


modified bases were marked as modified (details are available in Additional file 3). Corresponding motif information is included in Table 5.

\section{CRISPR system}

MinCED derived from the CRT [65], was used to predict CRISPR structure. CRISPR are extensively found in prokaryotes and are thought to compose a CRISPRassociated system, which is a putative immune system based on RNA-interference [66]. Three candidate CRISPR clusters on chromosome sequence were annotated under strict parameter and 1 CRISPR on plasmid (further information is available in Additional file 4).

\section{Genomic islands}

GEIs are particularly influential in microorganism genomes with regard to virulence, antibiotic resistance, metabolic, symbiosis, or other important adaptations [67]. GEIs have substantial roles in horizontal gene transfer, which is now widely acknowledged as an important force that shapes bacterial genome structure. Island Viewer (version 2.0) [68] was used to predict the GEIs in M. panniformis FACHB1757. Island Viewer integrates SIGI-HMM, Island Pick, and Island PathDIMOB and built-in databases, including the Virulence Factor Database and Antibiotic Resistance Gene Database. Thirty-six GEIs were found using Island Viewer, and their positions are shown in Fig. 6. Different kinds of functions were identified and are summarized in Table 6. Transposases were identified in most of the GEIs, as they participated in horizontal gene transfer. Toxin-related gene clusters were annotated in six GEIs and probably affect competitiveness and fitness. Some functional genes, such as hat/hatR, were also detected, which indicates the enhanced adaptability and metabolic versatility in this strain.

\section{Conclusions}

This study presents the complete whole genome sequence of a newly recorded species in China, M. panniformis, and demonstrates several genomic perspectives, including comparison with nine other water bloomforming cyanobacterial species. A 5.6 Mbp chromosome with a $38 \mathrm{Kbp}$ plasmid was reported, and gene function, methylation modification, CRISPR, and GEIs throughout the genome were described. Large-scale of structure variation was demonstrated by comparison with $M$. aeruginosa genomes. A Venn diagram of four Microcystis strains showed gene quantity and category variation as a result of evolutionary divergence and revealed that Microcystis has underwent flexible genome evolution.

\section{Additional files}

\begin{abstract}
Additional file 1: Tables S1-3 and Figures S1-5. Table S1. General
information regarding phylogenomics and comparative genomic analysis. Table S2. Function annotation assignment from different databases.

Table S3. Conserved gene cluster function and position in the genomes of four Microcystis strains. Figure $\mathbf{S 1}$. Whole genome comparison with M. aeruginosa NIES843 at the nucleic acid level. Large-scale structural rearrangement was obvious at the nucleic acid level. Blocks on the line for M. panniformis FACHB1757 show that the sequences of the two species were in the same direction, whereas blocks under the line indicated that the sequences ran in the opposite direction. Figure S2. Length distribution of annotated protein-coding genes. The majority of fractions varied in length from 100 to 150 . Figure S3. Subsystems and category distributions of genes. Functional annotation by RAST. Figure S4. Histogram demonstrating functional annotation results against GO. Figure S5. Number of each category in function annotation results against KEGG. (DOCX $599 \mathrm{~kb}$ )
\end{abstract}

Additional file 2: The COG function annotation in each COG cluster. (XLSX $114 \mathrm{~kb}$ )

Additional file 3: $\mathrm{N}^{4}$-methylcytosine, $\mathrm{N}^{6}$-methyladenine, and other modified bases throughout the whole chromosome. (XLSX $7893 \mathrm{~kb}$ )

Additional file 4: Annotation of three candidate CRISPR clusters on the chromosome sequence and one CRISPR cluster on the plasmid using strict parameters. (XLSX $14 \mathrm{~kb}$ )

\section{Abbreviations}

CRISPR: Clustered Regularly Interspaced Short Palindromic Repeats; CRT: CRISPR Recognition Tool; EPS: Extracellular polysaccharide;

GEIs: Genome islands; MinCED: Mining CRISPRs in Environmental Datasets; R-M: Restriction-modification; TRs: Tandem repeats.

\section{Competing interests}

The authors declare that they have no competing interests.

\section{Authors' contributions}

J-YZ and RG contributed equally to this paper. J-YZ carried out microscopy, sample collection and purification, and drafted the manuscript. RG carried out genomic perspective analysis, the genomic evolution analysis, and conceived the manuscript. HL participated in sample culture and genomic DNA extraction. PX provided information about the M. aeruginosa PCC7806 genome. LD and D-MC participated in genome assembly and annotation. $\mathrm{H}-J \mathrm{Z}$ and $\mathrm{B}-\mathrm{CZ}$ contributed technical assistance to sample collection and purification. $\mathrm{HL}$, PX and G-LY helped with discussions. Professor Z-HL and R-HL conceived the study, and its design and coordination, and helped draft the manuscript. All authors read and approved the final manuscript.

\section{Acknowledgements}

This work was performed under the authority of Wuxi Environmental Monitoring Center, the State Key Laboratory of Bioelectronics (Southeast University), and Institute of Hydrobiology (The Chinese Academy of Sciences). It was partially supported by Major Science and Technology Program for Water Pollution Control and Treatment (2012ZX07101-013-06) to HZ, the National Natural Science Foundation of China (No.61227803), and the NSFC-JST Project (No.41261140337). We thank Ting Song for mapping the collected strain location (Fig. 1a). We gratefully acknowledge the help of Mr. Ge (Director of Wuxi Municipal Environmental Protection Bureau, China) and Mr. Li (Deputy Director of Wuxi Municipal Environmental Protection Bureau, China) in the aspect of administrative support for this project.

\section{Author details}

${ }^{1}$ State Key Laboratory of Bioelectronics, School of Biological Sciences and Medical Engineering, Southeast University, Nanjing 210096, China. ${ }^{2}$ Wuxi Environmental Monitoring Center, Wuxi 214121, China. ${ }^{3}$ Institute of Hydrobiology, The Chinese Academy of Sciences, Wuhan, Hubei 430072, China. ${ }^{4}$ Shenzhen Key Laboratory for Marine Bio-resource and Eco-environment, College of Life Sciences, Shenzhen University, Shenzhen 518060, China. ${ }^{5}$ Nextomics Biosciences Co., Ltd., Wuhan, Hubei 430072, 
China. ${ }^{6}$ Department of Biomedical Engineering, College of Engineering, Peking University, Beijing 100871, China.

\section{Received: 4 September 2015 Accepted: 5 January 2016}

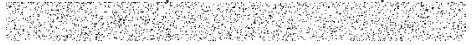

\section{References}

1. Bister B, Keller S, Baumann HI, Nicholson G, Weist S, Jung G, et al. Cyanopeptolin 963A, a Chymotrypsin Inhibitor of Microcystis PCC 7806. J Nat Prod. 2004;67: 1755-7. PubMed http://dx.doi.org/10.1021/np049828f

2. Kardinaal WEA,Visser PM. Dynamics of caynobacterial toxins. In: Codd G, Lindsay J, Young F, Morrison L, Metcalf J, editors. Harmful Cyanobacteria. Dordrecht, The Netherlands; 2005.p.25-40. http://dx.doi.org/10.1007/14020-3022-3_1.

3. Portmann C, Blom JF, Gademann K, Jüttner F. Aerucyclamides A and B: Isolation and Synthesis of Toxic Ribosomal Heterocyclic Peptides from the Cyanobacterium Microcystis aeruginosa PCC 7806. Journal of Natural Products. 2008;71:1193-1196. PubMed http://dx.doi.org/10.1021/np800118g.

4. Whitton BA. Microcystis. In: Šejnohová L, Maršálek, editors. Ecology of Cyanobacteria II: Their Diversity in Space and Time. Dordrecht, The Netherlands; 2012.p.195-228. http://dx.doi.org/10.1007/978-94-007-3855-3.

5. Paerl HW, Huisman J. Climate Blooms like it hot. Science. 2008:320:57-8. PubMed http://dx.doi.org/10.1126/science.1155398.

6. Weirich CA, Miller TR. Freshwater harmful algal blooms: toxins and children's health. Curr Probl Pediatr Adolesc Health Care. 2014;44:2-24. PubMed http://dx.doi.org/10.1016/j.cppeds.2013.10.007.

7. Trevino-Garrison I, DeMent J, Ahmed FS, Haines-Lieber P, Langer T, Ménager H, et al. Human illnesses and animal deaths associated with freshwater harmful algal blooms-kansas. Toxins. 2015;7:353. PubMed http://dx.doi.org/10.3390/ toxins7020353.

8. Jason S,Hayes PK. Molecular axonomy of Harmful Algae.In: Granéli E, Turner JT. editors. Ecology of Harmful Algae. Dordrecht, The Netherlands; 2006. p. 15-16. http://dx.doi.org/10.1007/978-3-540-32210-8.

9. Sanchis D, Padilla C, Del Campo FF, Quesada A, Sanz-Alferez S. Phylogenetic and morphological analyses of Microcystis strains (Cyanophyta/ Cyanobacteria) from a Spanish water reservoir. NOVA HEDWIGIA. 2005;81: 431-48. http://dx.doi.org/10.1127/0029-5035/2005/0081-0431.

10. Kondo R, Yoshida T, Yuki Y, Hiroishi S. DNA-DNA reassociation among a bloom-forming cyanobacterial genus, Microcystis. Int J Syst Evol Microbiol. 2000;50:767-70. PubMed http://dx.doi.org/10.1099/00207713-50-2-767.

11. Otsuka S, Suda S, Shibata S, Oyaizu H, Matsumoto S, Watanabe MM. A proposal for the unification of five species of the cyanobacterial genus Microcystis Kutzing ex Lemmermann 1907 under the rules of the Bacteriological Code. Int J Syst Evol Microbiol. 2001;51:873-9. PubMed http://dx.doi.org/10.1099/00207713-51-3-873.

12. Otsuka S, Suda S, Li R, Watanabe M, Oyaizu H, Matsumoto S, et al. Phylogenetic relationships between toxic and non-toxic strains of the genus Microcystis based on 165 to $23 S$ internal transcribed spacer sequence. FEMS Microbiol Lett. 1999; 172:15-21. PubMed http://dx.doi.org/10.1111/j.1574-6968.1999.tb13443.x.

13. Le Ai NV, Tanabe Y, Matsuura H, Kaya K, Watanabe MM. Morphological, biochemical and phylogenetic assessments of water-bloom-forming tropical morphospecies of Microcystis (Chroococcales, Cyanobacteria). Phycol Res. 2012;60:208-22. http://dx.doi.org/10.1111/j.1440-1835.2012.00650.x

14. Bittencourt-Oliveira MC, Moura AN, Gouvêa-Barros S, Pinto E. HIP1 DNA fingerprinting in Microcystis panniformis (Chroococcales, Cyanobacteria). Phycologia. 2007;46:3-9. http://dx.doi.org/10.2216/06-01.1.

15. Komárek J, Komárková-Legnerova J, Sant'Anna CL, Azevedo MTDP, Senna PAC. Two common Microcystis species (Chroococcales, Cyanobacteria) from tropical America, including M.panniformis sp. nov. Cryptogamie. Algologie. 2002;23:159-77.

16. White SH, Fabbro LD, Duivenvoorden LJ. Changes in cyanoprokaryote populations, Microcystis morphology, and microcystin concentrations in Lake Elphinstone (Central Queensland, Australia). Environ Toxicol. 2003;18: 403-12. PubMed http://dx.doi.org/10.1002/tox.10142.

17. Sant'Anna CL, Maria Teresa de PA, Pedro Américo CS, Komárek J, Komárková J. Planktic Cyanobacteria from São Paulo State, Brazil: Chroococcales Cianobactérias planctônicas do Estado de São Paulo, Brasil: Chroococcales. Revista Brasileira de Botânica. 2004; 27:213-227. http://dx.doi.org/10.1590/ S0100-84042004000200002.

18. Nguyen LTT, Cronberg G, Larsen J, Moestrup O. Planktic cyanobacteria from freshwater localities in Thuathien-Hue Province, Vietnam I. Morphology and distribution. NOVA HEDWIGIA. 2007;85:1-34. http://dx.doi.org/10.1127/00295035/2007/0085-0001

19. Borges JT, Sparrapan R, Guimarães JR, Eberlin MN, Augusti R. Chloroform formation by chlorination of aqueous algae suspensions: online monitoring via membrane introduction mass spectrometry. J Brazilian Cheml Soc. 2008; 19:950-5. http://dx.doi.org/10.1590/S0103-50532008000500021.

20. Luciana Retz de C, Pipole F, Werner VR, Haywood Dail Laughinghouse IV, Antonio Carlos MC, Rangel M, et al. A toxic cyanobacterial bloom in an urban coastal lake, Rio Grande do Sul state, Southern Brazil. Brazilian J Microbiol. 2008;39:761-9. PubMed http://dx.doi.org/10.1590/\$1517-838220080004000031.

21. Bittencourt-Oliveira MC, Cunha MCC, Moura AN. Genetic polymorphism in brazilian Microcystis spp. (Cyanobacteria) toxic and non-toxic through RFLPPCR of the cpcBA-IGS. Brazilian Archives Biol Technol. 2009;52:901-9. http:// dx.doi.org/10.1590/S1516-89132009000400014.

22. Caliskan M. Genetic Diversity of Brazilian Cyanobacteria Revealed by Phylogenetic Analysis.In: Bittencourt-Oliveira M, Piccin-Santos V, editors. Genetic Diversity in Microorganisms. 2012.p. 275-290. http://dx.doi.org/ $10.5772 / 33137$

23. Edvani MS, Cícero TSG, Catarina PSR, Silvia MLB. Ocorrência de Cianobactérias no Reservatório de Mundaú, no Estado de Pernambuco, no Período de Janeiro de 2010 a Novembro de 2011 / Occurrence of Cyanobacteria in Mundaú Reservoir, in Pernambuco State During January 2010 to November 2011. Vigilância Sanitária em Debate: Sociedade. 2013;1:35-42. http://dx.doi.org/10. 3395/vd.v1i3.40

24. Bittencourt-Oliveira MC, Chia MA, de Oliveira HS B, Araujo MKC, Molica RJR, Dias CTS. Allelopathic interactions between microcystin-producing and nonmicrocystin-producing cyanobacteria and green microalgae: implications for microcystins production. J Appl Phycol. 2015;27:275-84. http://dx.doi.org/10. 1007/s10811-014-0326-2.

25. Bittencourt-Oliveira MC, Kujbida P, Cardozo KHM, Carvalho VM, Moura AN, Colepicolo $\mathrm{P}$, et al. A novel rhythm of microcystin biosynthesis is described in the cyanobacterium Microcystis panniformis Komárek et al. Biochem Biophys Res Commun. 2005;326:687-94. PubMed http://dx.doi.org/10.1016/j. bbrc.2004.11.091.

26. Zhang JY, Zhu BC, Wu ZJ, Xu T, Lu ZH. Microcystis panniformis-A newly recorded species of Microcystis in China. J Lake Sci. 2012;24:647-50.

27. Paerl HW, Paul VJ. Climate change: links to global expansion of harmful cyanobacteria. Water Res. 2012:46:1349-63. PubMed http://dx.doi.org/10. 1016/j.watres.2011.08.002.

28. Paerl HW. Mitigating harmful cyanobacterial blooms in a human-and climatically-impacted world. Life (Basel, Switzerland). 2014; 4:988-1012 PubMed http://dx.doi.org/10.3390/life4040988.

29. Qin B, Zhu G, Gao G, Zhang Y, Li W, Paerl HW, et al. A drinking water crisis in Lake Taihu, China: linkage to climatic variability and lake management. Environ Manage. 2010;45:105-12. PubMed http://dx.doi.org/10.1007/s00267-009-9393-6.

30. Qin B, Xu P, Wu Q, Luo L, Zhang Y. Environmental issues of Lake Taihu China. Hydrobiologia. 2007;581:3-14. http://dx.doi.org/10.1007/s10750-006-0521-5.

31. Komárek J, Komárková J. Review of the European Microcystis-morphospecies (Cyanoprokaryotes) from nature. Czech Phycology, Olomouc. 2002;2:1-24.

32. Wood SA, Crowe ALM, Ruck JG, Wear RG. New records of planktonic cyanobacteria in New Zealand freshwaters. New Zealand J Botany. 2005;43: 479-92. http://dx.doi.org/10.1080/0028825X.2005.9512969.

33. Liu Y, Xu Y, Xiao P, Pan Q, Yu G, Li R. Genetic analysis on Dolichospermum (Cyanobacteria; sensu Anabaena) populations based on the cultureindependent clone libraries revealed the dominant genotypes existing in Lake Taihu, China. Harmful Algae. 2014;31:76-81. http://dx.doi.org/10.1016/j. hal.2013.09.012.

34. Li L, Stoeckert Jr CJ, Roos DS. OrthoMCL: identification of ortholog groups for eukaryotic genomes. Genome Res. 2003:13:2178-89. PubMed http://dx. doi.org/10.1101/gr.1224503.

35. Tamura K, Stecher G, Peterson D, Filipski A, Kumar S. MEGA6: Molecular Evolutionary Genetics Analysis version 6.0. Mol Biol Evol. 2013;30:2725-9. PubMed http://dx.doi.org/10.1093/molbev/mst197.

36. Frangeul L, Quillardet P, Castets AM, Humbert JF, Matthijs HC, Cortez D, et al. Highly plastic genome of Microcystis aeruginosa PCC 7806, a ubiquitous toxic freshwater cyanobacterium. BMC Genom. 2008:9:274. PubMed http://dx.doi. org/10.1186/1471-2164-9-274.

37. Rantala A, Fewer DP, Hisbergues M, Rouhiainen L, Vaitomaa J, Borner T, et al. Phylogenetic evidence for the early evolution of microcystin synthesis. Proc Natl Acad Sci U S A. 2004;101:568-73. PubMed http://dx.doi.org/10.1073/pnas. 0304489101 
38. Schirrmeister BE, De Vos JM, Antonelli A, Bagheri HC. Evolution of multicellularity coincided with increased diversification of cyanobacteria and the Great Oxidation Event. Proc Natl Acad Sci U S A. 2013;110:1791-6. PubMed http://dx. doi.org/10.1073/pnas.1209927110.

39. Schirrmeister BE, Antonelli A, Bagheri HC. The origin of multicellularity in cyanobacteria. BMC Evol Biol. 2011;11:45. PubMed http://dx.doi.org/10.1186/ 1471-2148-11-45.

40. Palinska KA, Surosz W. Taxonomy of cyanobacteria: a contribution to consensus approach. Hydrobiologia. 2014;740:1-11. http://dx.doi.org/10. 1007/s10750-014-1971-9.

41. Dvořák P, Poulíčková A, Hašler P, Belli M, Casamatta D, Papini A. Species concepts and speciation factors in cyanobacteria, with connection to the problems of diversity and classification. Biodivers Conserv. 2015;24:1-19. http://dx.doi.org/10.1007/s10531-015-0888-6.

42. Kasai F, Kawachi M, Erata M, Watanabe MM. NIES-Collection, List of Strains: Microalgae and Protozoa. In: Kasai, F., Kawachi, M., Erata, M., Watanabe, M.M., editors. National Institute for Environmental Studies. Japan, Tsukuba; 2004.P. 257.

43. Chaisson MJ, Tesler G. Mapping single molecule sequencing reads using basic local alignment with successive refinement (BLASR): application and theory. BMC Bioinformatics. 2012;13:238. PubMed http://dx.doi.org/10.1186/ 1471-2105-13-238.

44. Miller JR, Delcher AL, Koren S, Venter E, Walenz BP, Brownley AC, et al. Aggressive assembly of pyrosequencing reads with mates. BMC Bioinformatics. 2008;24:2818-24. PubMed http://dx.doi.org/10.1093/ bioinformatics/btn548.

45. Chin CS, Alexander DH, Marks P, Klammer AA, Drake J, Heiner C, et al. Nonhybrid, finished microbial genome assemblies from long-read SMRT sequencing data. Nat Methods. 2013;10:563-9. PubMed http://dx.doi.org/10. 1038/nmeth.2474.

46. Benson G. Tandem repeats finder: a program to analyze DNA sequences. Nucleic Acids Res. 1999;27:573-80. PubMed http://dx.doi.org/10.1093/nar/27. 2.573 .

47. Aziz RK, Bartels D, Best AA, DeJongh M, Disz T, Edwards RA, et al. The RAST Server: rapid annotations using subsystems technology. BMC Genomics. 2008:9:75. PubMed http://dx.doi.org/10.1186/1471-2164-9-75.

48. Jones P, Binns D, Chang HY, Fraser M, Li W, McAnulla C, et al. InterProScan 5: genome-scale protein function classification. Bioinformatics (Oxford, England). 2014; 30:1236-1240. PubMed http://dx.doi.org/10.1093/bioinformatics/btu031.

49. Gan N, Xiao Y, Zhu L, Wu Z, Liu J, Hu C, et al. The role of microcystins in maintaining colonies of bloom-forming Microcystis spp. Environ Microbiol. 2012;14:730-42. PubMed http://dx.doi.org/10.1111/j.1462-2920.2011.02624.x.

50. Tanabe $Y$, Watanabe MM. Local expansion of a panmictic lineage of water bloom-forming cyanobacterium Microcystis aeruginosa. PloS One. 2011;6: e17085. PubMed http://dx.doi.org/10.1371/journal.pone.0017085.

51. Zhu W, Dai X, Li M. Relationship between extracellular polysaccharide (EPS) content and colony size of Microcystis is colonial morphology dependent. Biochem Sys Ecol. 2014;55:346-50. http://dx.doi.org/10.1016/j.bse.2014.04.009.

52. Zhao L, Lu L, Li M, Xu Z, Zhu W. Effects of Ca and Mg levels on colony formation and EPS content of cultured M. aeruginosa. Procedia Environmental Sciences. 2011; 10, Part B:1452-1458. http://dx.doi.org/10. 1016/j.proenv.2011.09.232.

53. Liu Y, Wang W, Geng L, Chen Y, Yang Z. Polysaccharide content and morphology of Microcystis aeruginosa in response to changes in metabolic carbon flux. Fresenius Environ Bull. 2011;20:1046-50.

54. Li M, Zhu W, Gao L, Lu L. Changes in extracellular polysaccharide content and morphology of Microcystis aeruginosa at different specific growth rates. J Appl Phycol. 2013;25:1023-30. http://dx.doi.org/10.1007/s10811012-9937-7.

55. Kehr JC, Zilliges Y, Springer A, Disney MD, Ratner DD, Bouchier C, et al. A mannan binding lectin is involved in cell-cell attachment in a toxic strain of Microcystis aeruginosa. Mol Microbiol. 2006;59:893-906. PubMed http://dx. doi.org/10.1111/j.1365-2958.2005.05001.x.

56. Hayes PK, Lazarus CM, Bees A, Walker JE, Walsby AE. The protein encoded by $g v p C$ is a minor component of gas vesicles isolated from the cyanobacteria Anabaena flos-aquae and Microcystis sp. Mol Microbiol. 1988;2:545-52. PubMed.

57. Mlouka A, Comte K, Castets A-M, Bouchier C, Tandeau de Marsac N. The Gas Vesicle Gene Cluster from Microcystis aeruginosa and DNA rearrangements that lead to loss of cell buoyancy. J Bacteriol. 2004;186:2355-65. PubMed.
58. Dunton PG, Walsby AE. The diameter and critical collapse pressure of gas vesicles in Microcystis are correlated with GvpCs of different length. FEMS Microbiol Lett. 2005;247:37-43. PubMed.

59. Hauman J. Is a Plasmid(s) Involved in the Toxicity of Microcystis aeruginosa? In: Carmichael WW, editor.The Water Environment. US; 1981. p. 97-102. http://dx.doi.org/10.1007/978-1-4613-3267-1_7.

60. Schwabe W, Weihe A, Börner T, Henning M, Kohl J-G. Plasmids in toxic and nontoxic strains of the cyanobacterium Microcystis aeruginosa. Curr Microbiol. 1988;17:133-7.

61. Bolch CJS, Blackburn SI, Jones GJ, Orr PT, Grewe PM. Plasmid content and distribution in the toxic cyanobacterial genus Microcystis Kützing ex Lemmermann (Cyanobacteria: Chroococcales). Phycologia. 1997;36:6-11. http://dx.doi.org/10.2216/i0031-8884-36-1-6.1.

62. Darling AC, Mau B, Blattner FR, Perna NT. Mauve: multiple alignment of conserved genomic sequence with rearrangements. Genome Res. 2004;14: 1394-403. PubMed http://dx.doi.org/10.1101/gr.2289704.

63. Roberts RJ, Vincze T, Posfai J, Macelis D. REBASE-a database for DNA restriction and modification: enzymes, genes and genomes. Nucleic Acids Res. 2010;38:D234-6. PubMed http://dx.doi.org/10.1093/nar/gku1046.

64. Roberts RJ, Vincze T, Posfai J, Macelis D. REBASE-enzymes and genes for DNA restriction and modification. Nucleic Acids Res. 2007;35:D269-270. PubMed http://dx.doi.org/10.1093/nar/gkl891.

65. Bland C, Ramsey TL, Sabree F, Lowe M, Brown K, Kyrpides NC, et al. CRISPR recognition tool (CRT): a tool for automatic detection of clustered regularly interspaced palindromic repeats. BMC Bioinformatics. 2007;8:209. PubMed http://dx.doi.org/10.1186/1471-2105-8-209.

66. Haft DH, Selengut J, Mongodin EF, Nelson KE. A guild of 45 CRISPR-associated (Cas) protein families and multiple CRISPR/Cas subtypes exist in prokaryotic genomes. PLoS Comput Biol. 2005;1:e60. PubMed http://dx.doi.org/10.1371/ journal.pcbi.0010060.

67. Dobrindt U, Hochhut B, Hentschel U, Hacker J. Genomic islands in pathogenic and environmental microorganisms. Nat Rev Microbiol. 2004;2:414-24. PubMed http://dx.doi.org/10.1038/nrmicro884.

68. Langille MG, Brinkman FS. IslandViewer: an integrated interface for computational identification and visualization of genomic islands. Bioinformatics. 2009;25:664-5. PubMed http://dx.doi.org/10.1093/bioinformatics/btp030.

69. Field D, Garrity G, Gray T, Morrison N, Selengut J, Sterk P, et al. The minimum information about a genome sequence (MIGS) specification. Nat Biotechnol. 2008;26:541-7. PubMed http://dx.doi.org/10.1038/nbt1360.

70. Woese CR, Kandler O, Wheelis ML. Towards a natural system of organisms: proposal for the domains Archaea, Bacteria, and Eucarya. Proc Natl Acad Sci U S A. 1990;87:4576-9. PubMed http://dx.doi.org/10.1073/pnas.87.12.4576.

71. McNeill J, Barrie FR, Burdet HM, Demoulin V, Hawksworth DL, Marhold K, et al. International Code of Botanical Nomenclature. Königstein: A.R.G. Ganter; 2006. p. 1.

72. Woese CR, Stackebrandt E, Macke TJ, Fox GE. A phylogenetic definition of the major eubacterial taxa. Syst Appl Microbiol. 1985;6:143-51. PubMed http://dx.doi. org/10.1016/S0723-2020(85)80047-3.

73. Stanier RY, Kunisawa R, Mandel M, Cohen-Bazire G. Purification and properties of unicellular blue-green algae (order Chroococcales). Bacteriol Rev. 1971;35:171-205. PubMed.

74. Komárek J, Anagnostidis K. Cyanoprokaryota 1. Teil: Chroococcales. In: Ettl H, Gartner G,Heynig H, Molllenhauer D, editors. Süßwasserflora von Mitteleuropa. 1999.p.164-169.

75. Geitler L. Cyanophyceae. In: Rabenhorst L, von Deutschland KF, editors. Österreich und der Schweiz Leipzig: Akademische Verlagsgesellschaft, vol. 14. 1932. p. 130-59.

76. Caumette $P$, Brochier-Armanet $C$, Normand $P$. Taxonomy and Phylogeny of Prokaryotes. In: Bertrand J-C, Caumette P, Lebaron P, Matheron R, Normand P, Sime-Ngando T, editors. Environmental Microbiology: Fundamentals and Applications. Netherlands: Springer; 2015. p. 177-9. http://dx.doi.org/10.1007/ 978-94-017-9118-2_6

77. Via-Ordorika L, Fastner J, Kurmayer R, Hisbergues M, Dittmann E, Komarek J, et al. Distribution of microcystin-producing and non-microcystin-producing Microcystis sp. in European freshwater bodies: detection of microcystins and microcystin genes in individual colonies. Syst Appl Microbiol. 2004;27:592602. PubMed http://dx.doi.org/10.1078/0723202041748163.

78. Ashburner M, Ball CA, Blake JA, Botstein D, Butler H, Cherry JM, et al. Gene ontology: tool for the unification of biology. The Gene Ontology Consortium. Nature genetics. 2000; 25:25-29.PubMed. http://dx.doi.org/10.1038/75556. 